\title{
BYBELSE AGTERGROND VAN DIE BARMHARTIGHEIDSDIENS VAN DIE KERK EN DIE AMP VAN DIE DIAKEN
}

\author{
DS. E. ENGELBRECHT.
}

\section{WOORDOMSKRYWING.}

Diakonaal: van, vanweë die diakonie.

Diakonaat: omvattende benaming vir alles, bv. die leer, samestelling, amp, uitoefening ens. i.v.m. die diakonie; soms ook gebruik as wisselvorm vir diakonie.

Diakonie: al die diakens van 'n gemeente of van al die gemeentes van die kerk, saamgevat as liggaam of kollege wat belas is met die insameling en uitdeel van liefdegawes en met alle barmhartigheidsdiens . . .; kerklike barmhartigheidsdiens, armbestuur.

(W.A.T. 2, Pretoria 1955).

\section{INLEIDING.}

\section{A. OPDRAG.}

Hierdie studie wil na die Bybelse agtergrond van die barmhartigheidsdiens van die gemeente en van die diaken in die besonder vra. Daar wil antwourd gegee word op die vraag na die eintlike opdrag in die barmhartigheidsdiens aan die gemeente en die diaken. Verder sal ook gevra word na die verhouding tussen die gemeente en die diaken terwyl hulle barmhartigheid doen. Die ondersoek wil dan veral hierdie vraag vra en antwoord in die lig van die Heilige Skrif. Daar sal egter ook 'n uitstappie in die geskiedenis gemaak word om te kyk hoe die amp van diaken in die verlede (en die hede) dikwels gevul is. Die Bybelse besinning van die kerk sal eers dan sy opdrag „volledig" uitgevoer het as hy hom ook teenoor die dwaalleringe afgegrens het. Soos dalk nêrens anders in die kerk nie, word hierdie dwaalleer rondom die diens van die diaken in die dwaalhandeling duidelik.

Die geskiedenis sal ook heenwysig wees in watter rigting ons die fundamentele opdrag aan die diaken moet soek. Dit sal meebring dat ons in die beantwoording van dié vraag nie eensaam sal wees nie - of bo alles - dat ons die amp nie eiesinnig sal vul nie. Dit is veral eers as mens hierdie vraag gevra het en 'n antwoord begin soek het, dat mens sien dat die vraag nie te vinnig gevra moet word nie en ook nie te gou beantwoord kan word nie. Die kortheid van hierdie ondersoek lê dan nie by 
die ondersoek nie, maar by die opdrag. Uit die ondersoek het dit toe duidelik geword dat die opdrag alleen só verstaan kan word dat daar slegs 'n begin gemaak sal word met die vraag en die antwoord oor die fundamentele opdrag aan die diaken.

\section{B. 'N AKTUELE VRÁAG.}

Die vraag na die inhoud van die amp van die diaken is tans 'n aktuele vraag - om verskillende redes. Dit is ' $n$ vraag wat veral die laaste twintig jaar brandend geword het. As P. J. Roscam-Abbing in 1950 met die titel „Diakonia" 'n studie oor die begrip diens in die dogmatiek en praktiese teologie maak, is dit nie moontlik om 'n literatuurlys te noem nie "vanwege de geringheid van goede geschriften." Van toe af het 'n stroom studies oor die onderwerp verskyn sodat die literatuuropgawe tans honderde titels bevat.

\section{Aktueel in die ekumeniese beweging.}

Die diakonale amp van die kerk') is 'n vraag waaraan die ekumeniese beweging baie aandag gee. Want die moderne kerk wil wees en besig wees - tuis wil hy besig wees met die diakonie en verder weg met die ontwikkelingshulp. Die "probleem" vir die navorier van die Wêreldraad van Kerke is dat die Nuwe Testament so vaag is oor die amp van die diaken of dat verskillende tekste hul tot botsende uitleg leen.

Alreeds die Internasionale Sendingsraad wat in 1928 te Jerusalem vergader, stel die skema, boodskap (Kērugma), gemeenskap (koinónia), diens (diakonia) op. Hierdie skema word voorbereiding vir die sg. "comprehensive approach" waarmee die ekumeniese beweging vandag werk. Die probleem waarmee die ekumeniese beweging spook, is hoe 'n moderne wêreld die evangelie sal aanneem (wêreld: vervalle kerk! en heidendom). Die oplossing van die probleem word dan gesien in die metode „comprehensive approach". Hierdie begrip het 'n Anglo-saksiese oorsprong met 'n Hollandse fundering!") Eers as die mens in sy totale betrekking aangespreek word, sal hy kan hoor en gehoor gee. As die kerk die wêreld net met die prediking benader, het die kerk nog nooit erns met die wêreld as wêreld gemaak nie en neem die kerk hierdie nuwe objek (Gegenüber) van sy evangelisasie nie errstig op nie. Die nuwe objek (Gegenüber) moet beslissend meespreek in die gestalte van die evangelie. En hierom moet die evangelisasie meer wees as net blote prediking. Daa:om

1) Das Diakonische Amt der Kirche im Okumenishen Bereich, herausgegeben von $\mathrm{H}$. Krimm, Stuttgart, 1960.

2) H. S. Margull, Thelogie der Missionarischen Verkündigung, Stuttgart 1959 , S. 191 . 
tipeer Evanston blote prediking as „verbalisme.”3) Hierdie verbale kommunikasie, wat erfenis van die Reformasie is, is 'n ernstige degenerasie van die profetiese karakter van die Woord. Evangelisasie het twee brandpunte nl. verkondiging (kērugma) en gemeenskap (koinónia). Maar altwee word in die wêreld voltrek deur diakonia (diens). Daarom moet daar - so word by Whitbey gemeen - 'n herlewing in die kerke kom. Die kerk moet weer "tot die oord van God se teenwoordigheid word en tot woonplek van die Heilige Gees." (K. Hartenstein). ,Die evangelie begin met die goddelike aktiwiteit, maar eindig nie daarmee nie.” „Die opvoeding van die jeug, die genesing van die liggaam, sorg vir wese en oues van dae in integrale en onlosbare bestanddele van die verkondiging van die Ryk van God." Die Woord van God alleen is nie genoeg nie. Die menslike aktiwiteit moet die goddelike aktiwiteit uitbrei en ondersteun. (C.I.M.C. Whitbey, 1 Julie 1947). Van hieruit word dan gestel: "The Messianic era is revealed in terms of physical liberation.") Sending gaan gewoonweg oor en op in diakonaat. Vir die ekumeniese beweging beteken "brood vir die wêreld" sondermeer 'n broodvraag. Die nood van die wêreld is die hongersnood, en ongelykheid. Die diakonaat van die kerk word veral gesien as die skep van lewensmoontlikhede vir die miljoene van die wêreld (83\%) wat net beheer oor $20 \%$ van die totale besit het. Die kerk sal hierdie struktuur moet help deurbreek, want dit is hierdie wanverhouding wat oorsaak is van die wêreldnood.5) Die kerk moet meedoen - nog beter - leier van die ekonomies-sosiale rewolusie word. ,The task of the church today is, in a sentence, to recover its leadership in the revolution. From the beginning, and in its essential nature, the church has been revolutionary. Christ sent it out as an explosive, corrosive, destructive force." () Die diakonia (só verstaan) word dan tot „esse" van die kerk. Dit is dus te verstane dat die diakonaat van die kerk in die ekumeniese beweging die eerste plek inneem en dat deur die ekumeniese diskussie die saak besonder dringend geword het. Dit is ook duidelik dat die ,amp van die diaken" vir die ekumeniese beweging die eintlike amp is. Verder is dit duidelik dat hulle die ,amp' op 'n besondere wyse gevul het.

Die diakensamp kry hier geweldige en opwindende dimensies. Die „hele kerk" staan hier in diens van die "hele wêreld" en hou hom nie alleen besig met probleme oor die hele wêreld nie, maar

3) Margull, a.w., S. 189.

4) Chandran, soos aangehaal deur Margull, a.w., S. 193.

5) D. J. Karres, De gemeente en haar diakonaat, 's. Gravenhage, 1969, bl. 124.

${ }^{\circ}$ ) St. C. Neill, A Revolutionary Church, (Whitbey 62-84) p. 75, 64. 
veral ook met wêreld-omvattende probleme. Hierdeur begin die diaken meespreek met die magtiges van die wêreld oor wêreldprobleme. En hier wil die kerk ten minste meespreek, liefs leiding gee. Hier is die kerk in die geselskap van die makrostrukture. Die begrip diakonein (so sal aangetoon word) sal ons verhinder om met die makrostrukture te wil meespreek - ons kan die makrostruktuur net „dien”. Geweldige en minder geweldige bedrae word bestee aan vlugtelingehulp en ondersteuning van terroriste. Hier word die diaken nou aktief besig met die rekonstruksie van die sosiaal-ekonomiese struktuur van hele lande oor die hele wêreld - ja, van die hele wêreld. Duisende en miljoene word die faktore waarmee gewerk word. Persoonlike nood is nou nie soseer die voorwerp waarop die diens gerig is nie, maar die groter node van wêreldformaat soos bv. die wapenwedloop en die koue oorlog. "It is not a question of preserving a ,timehonoured function', the ,diaconal function' in the church must find expression in a way suited to our own day."')

Die amp van die diaken het in die ekumeniese beweging ook brandend geword toe kerke begin verenig het. Die verenigde kerk moes dikwels die aard en funksie van die diakonaat nuut konstrueer. (Bv. die kerk van Suid-Indië). Die skerp verskille wat tussen kerke rondom die ampte bestaan, het tot studie van die ampte gedwing (ook die diakensamp!)

Die diakonaat het ook vir die ekumeniese beweging van groot belang geword in die ",kontemporêre gemeenskap". Die situasie is vandag so dat baie filosofiese en godsdienstige sisteme juis besig is om 'n beter wêreld te skep. Met hierdie sisteme sal die kerk moet meeding op hierdie vlak anders sal sy boodskap nooit aanvaar word nie, want die wêreld vra na "fruits" nie na "roots" nie. Die kerk sal deur oortreffing van die huidige sisteme deur sy ,fruits' na die bron moet lei. ${ }^{8}$ )

\section{Maar ook by ons.}

Die vraag na die amp van die diaken het die afgelope jare ook in die Hervormde kerk al meer na vore gekom. Veertien jaar gelede al het prof. B. J. Engelbrecht 'n stel dringende vrae rondom die amp van diaken gevra, juis omdat ander opdragte sy eintlike opdrag verdring het. ${ }^{9}$ ) In die jongste tyd is dit veral prof. A. D. Pont wat vraagtekens begin sit agter die kerkregtelike reëlings rondom die diakonaat. ${ }^{10}$ ) Tydens die Algemene Kerkvergadering

i) L. Vischer, The Ministry of Deacons, W.C.S. 2, Geneva, 1955, p. 19.

8) The Role of the diakonia of the Church in contemporary society, W.C. of C. Geneva 1966, p. 15.

9) B. J. Engelbrecht, Die Amp van die diaken, Krugersdorp 1957, bl. 34.

10) A. D. Pont, Almanak 1969, bl. 60. 
van 1970 , het vrae rondom die amp van diaken sterker na vore getree deur verskillende beskrywingspunte (V. 12, V. 13, V. 14, $\mathrm{V}$. 15) en besluite (veral as vergunning gegee word om vroue tot die diakensamp te verkies.)

\section{MOTIEWE VIR BARMHARTIGHEID?}

Onder die heel vroegste impulse tot barmhartigheid is die loongedagte. Van die tweede eeu af begin die loongedagte die genade in die teologie oorheers en dit het dan ook vir die diakensamp en die barmhartigheid gevolge. Die beloning word tot die sterkste impuls vir barmhartigheid. „Verder, so 'n loon word bestem vir die wat meedeel - 'n ewige tent!" "1) So stel Ambrosius (C. 390) dat aalmoese vry van sonde maak. ${ }^{12}$ )

Maar om na motiewe vir die barmhartigheidsdiens te vra, bly 'n gevaarlike onderneming, want watter motief mens ookal aanvoer, motiewe het nog altyd onmagtig blyk te wees om tot barmhartigheid aan te spoor. Eintlik is die barmhartigheidsdiens ongemotiveerd, (soos trouens ons hele lewe - uit dankbaarheid) want dit gaan hier om geloofsgehoorsaamheid wat ongemotiveerd is en alle motiewe hul motiveringskrag ontneem. Hierom was ook die ,hoogste” motief: „ons moet Christus navolg", telkens onmagtig om tot barmhartigheid aan te spoor.

Die barmhartigheidsdiens van die gemeente het sy oorsprong in die gemeenskap van die gelowiges. Die gemeenskap van die gelowiges beteken egter in die eerste plek dat ons almal saam en elkeen afsonderlik as lede aan die Here Christus en al sy gawes en skatte gemeenskap het. Die gelowige kan dus „iets” gee, omdat hy so „baie" het - ons het gemeenskap aan die Here Christus self. Die gelowige wat in gemeenskap wil tree met sy medegelowige het gemeenskap met „die Vader en met sy Seun, Jesus Christus" (Joh. 1:3). Saam met Christus skenk die Vader ons alles genadiglik (Rom. 8:32).

Maar hierdie gemeenskap aan Christus beteken ook 'n gemeenskap met mekaar. Elkeen moet sy gawes tot nut en saligheid van die ander lede gewillig en met vreugde aanwend. Ons lewe staan in die teken van God se gawe. Meer nog - ons lewe omdat God altyd gee - omdat God sy Seun en deur die Seun sy Heilige Gees aan ons gegee het. Hierom kan ons God ook tereg die Gewer noem. So dikwels as wat God ons ontmoet, gee Hy. En hierom word ook ons tot gewers. Ons sal altyd moet onthou dat die grootste gawe wat ons het Jesus Christus self is en dat die

11) Clemens Alexandrinus (C. 150-C. 215) soos aangehaal deur H. Krimm, Quellen zur Geschichte der Diakonie, Stuttgart, S. 47.

12) H. Krimm, a.w., S. 68 . 
grootste wat ons kan gee, daarom ook $\mathrm{Hy}$ is. Dit is dan ook die eintlike en grootste nood van elke mens dat hy behoefte aan Christus het.

Maar ons wat ons deel het aan Christus en al sy gawes so moet ons ook al ons gawes vrywilliglik en met vreugde aanwend tot voordeel van ons mede-gelowiges.

Die gemeenskap van die gelowiges beteken ook dat ons saam sal bely. Die gemeenskap van die gelowiges het ook die gemeenskaplike belydenis van die gemeente voor oë. Ons bely saam dat Hy onse Profeet is. Uit die gemeenskap van die gelowiges vloei die ver/antwoord/elikheid vir mekaar sodat niemand uit hierdie belydenis gemeenskap sal uitval nie.

Hierdie saam bely as grond en doel van die barmhartigheid is juis die punt wat barmhartigheidsdiens van welsynswerk skei. Dit is ook die krisis wat meebring dat ons die opwindende en groot hulp van die Wêreldraad van Kerke aan vlugtelinge en terroriste met enige woord kan beskryf, behalwe met barmhartigheidsdiens. Dit is tragies dat juis die koinonia, ${ }^{13}$ ) as impuls en doel van die ekumeniese beweging in sy „barmhartigheid" skipbreuk ly. Die kerk sal altyd op vreemde paaie kom as die Woordverkondiging vir hom, verbalisme 'word. As die Woordverkondiging vir die kerk verstikkend word en 'n te geringe opdrag blyk te wees en die kerk daarom breër weë wil bewandel, sal hy gou op hierdie breër weg verstik word.

\section{CHRISTUS EN DIE DIAKENSAMP.}

\section{A. EK IS IN JULLE MIDDE SOOS EEN WAT' DIEN.}

As ons die diens van Jesus Christus vanuit die vleeswording sien, sal ons dit ook sien as 'n ,sigself ontleding' (Filip. 2:7 II Kor. 8:9!) Die nederigheid en die diens (diakonein) is nooit toevallige elemente van Christus se werk nie. Sy werk is nooit iets anders as diens nie.

Die vraag is hoe ons die was van die dissipels se voete moet verstaan (Joh. 13) en dat Jesus sê dat Hy onder die dissipels "soos een wat dien" is. En verder: Wat hou dit in en hoe moet ons dit verstaan as Jesus Christus sy, diens' as opdrag aan die dissipels gee? (Mark. 10:42-45 en Matt. 20:25-28). Die beantwoording van die vraag oor hoe ons Jesus se dien moet verstaan, sal vir die diakonaat, trouens alle ampte, rigtinggewende betekenis

13) koinónia is o.a. 'n totale saamwees - as mens wil: mitmachen! Dit is ook die skeiding tussen kameraadskap en broerskap, want koinónia is ook saam bely. 
hê. ${ }^{14}$ ) Ons sal die begrip diakonein hier (Luk. 22:25-27 en Matt. $20: 28)$ in sy breedste betekenis moet verstaan. Jesus gee aan die woord diakonēsai sy inhoud as Hy sê: „en sy lewe te gee as 'n losprys vir baie". Die was van die dissipels se voete is dan ook heenwysing na sy kruisiging. As Jesus aan sy kerk die opdrag tot diens gee, (Matt. 20:26 en Joh. 12:26) is dit dus meer as net barmhartigheid. Maar juis hierom is die nederige barmhartigheidsdiens ook ingesluit. Vir die gelowige wat Jesus volg, gaan dit nooit om eie belang nie, maar om die belang van ander. (Joh. 12:25-26). Die volg van Jesus kom ook ter sprake in Matt. 20:28. Hier het die „,net soos" (ósper) nie net vergelykende krag nie, maar ook motiverende krag. Want die verbintenis met die Heer is nie die van voorbeeld ${ }^{15}$ ) en navolging nie, maar is veel eerder ' $n$ verbintenis deur geloof en liefde. Die verlossing deur Jesus Christus is nie 'n magsvertoning nie, maar 'n daad van selfoorgawe en vernedering (kenósis) in gehoorsaamheid aan sy opdrag. Deur die "net soos" word die dissipels tot apostels hulle kry nou 'n opdrag. Hulle moet die vele versamel vir wie Jesus gesterf het. Nou word hulle ook gewaarsku teen heerssug en word hulle daarop gewys dat hulle gehoorsaamheid altyd los moet staan van selfsugtige motiewe deur na mag en grootheid te gryp. Alleen in die onbaatsugtige liefde van die apostels sal die "vele" erken wat Jesus Christus deur sy kruis aan hulle gegee het. ${ }^{16}$ ) Maar hierdie opdrag moet ook só gesien word dat Christus sy opdrag nog nooit aan mense oorgegee het nie. Eintlik is dit die Here self wat nou nog in die gemeente dien deur sy Woord en Gees. ${ }^{1 T}$ )

\section{B. CHRISTUS EN DIE DIAKENSAMP.}

\section{In die Nuwe Testament.}

Die begrip diakonein het dus in die Nuwe Testament 'n noue verbintenis met Christus. Die verbintenis word ook in I Kor. 12:4-6 gehandhaaf. Hier word die charismata aan die Gees, die diakoniai aan Christus en die energēmata aan God toegewys. Hierdie toewysing is nie retories nie, maar saaklik bepaald.".) (Vgl. I Kor. 3:5). Die diakoniai is gawe van die Here aan sy gemeente.

14) Word diakonein hier in sy engere betekenis verstaan, word die diakonaat die belangrikste of selfs enigste werk van die kerk.

1.5) Die navolging van Jesus se voorbeeld speel by die teologie van die Wêreldraad van Kerke 'n belangrike rol;

The Role of the Diakonia of the church in contemporary society, W.C. of C., Geneve 1966, p. 16 .

16i) A. Schlatter, Der Evangelist Matthëus, Stuttgart 1959 by Matt. 20:28.

ii) Hoedemaker beklemtoon hierdie gedagte al lankal. Hier word alle vertikale hierargie in beginsel onmoontlik gemaak.

ix) II. Conzelmann, Erster Kurintherbrief, Göttingen 1969, S. 245. 


\section{By Ignatius.}

Ignatius sien hierdie besondere verhouding tussen Christus en die diakonaat raak! „So moet almal aan die diakens eer betoon soos aan Jesus Christus, soos wat die biskop dan ook 'n tipe van die Vader is, en die ouderlinge as die raad van God die vergadering van apostels" (Trall. 3,1 ) en: . . ., aan die diakens, wat vir my besonder geliefd is, is die diens van Jesus Christus toevertrou". (Magn. 6, 1) en verder sê hy in Trall. 2, 3 dat aan die diakens die verborgenhede van Christus toevertrou is. (musterion Jesou Christou).

\section{Uit die wese van die kerk.}

Die diakensamp, (soos trouens al die ampte) kom uit die wese van die kerk. ${ }^{19}$ ) Die ampte word nie van buite af deur wêreldse node of deur menslike goeddunke aan die kerk toegevoeg nie. Die diakensamp is gawe van Christus - $\mathrm{Hy}$ is die gesalfde, die eintlike diaken.

\section{Reformasie en amp.}

Toe die Reformasie tot die regte en volle ontplooing van Christus se amp gekom het, toe is daar ook wat die ampte betref, eers tot 'n hervorming en volle ontplooiing gekom. Die Reformatore wil dit duidelik stel dat Jesus Christus nooit anders as vir ons is nie. Dit gaan vir Hom nooit om sy privaat lewe nie. Hy het nooit eie tyd nie. Maar Hy doen nie net alles wat Hy doen vir ons nie, maar Hy is ook alles wat $\mathrm{Hy}$ is vir ons. (Dit geld vir die verlede, die hede en die toekoms). Selfs sy geboorte het hierdie betekenis. (Heidelbergse Kategismus Vr. en antw. 36). Hierdie "vir ons" in diens en wese word selfs tot die ewigheid teruggevoer. Hy is die ewige Seun van God. (Heidelbergse Kategismus Vr. en antw. 33).

„Deze centraal-religieuse (G. C. Berkouwer) reiniging van de christelijke eksistentie is gepaard gegaan met een ongehoorde nadruk op de middelaarspositie van Jesus (Heidelbergse Cat. Zondag II), dat is, in de taal van ons onderwerp, op de ambtelijkheid! Het ligt daarom voor de hand, dat in een genuien-reformatorische religie en kerk de ambten ook een centraal religieuse betekenis hebben". ${ }^{20}$ )

\section{Sin van die diakonaat.}

Die diens waartoe ons geroep is, is meer as 'n diens aan mekaar - dit is diens aan Christus. Die begrip diakonein is nie 'n etiese, sosiale of politieke begrip nie, maar 'n eskatologiespraedestinatiaanse. (A. A. van Ruler). Die diakonaat moet so in

19) A. van Ruler, Bijzonder en Algemeen Ambt, p. 70 .

20) A. A. van Ruler, Bijzonder en Algemeen Ambt, p. 72. 
die wëreld voltrek word dat God en sy saak gedien word. (II Kor. 9:12-13).

„Want die bediening van hierdie hulpbetoning voorsien nie alleen in die behoeftes van die heiliges nie, maar is ook oorvloedig deur baie danksegginge aan God, ${ }^{21}$ ) omdat hulle deur die bewys van hierdie diens God verheerlik oor die onderwerping van julle belydenis aan die evangelie van Jesus Christus en oor die mildadigheid van die bydrae aan hulle en aan almal".

I. Petr. 4:11:

„... as iemand dien, laat dit wees soos uit die krag wat God verleen, sodat God in alles verheerlik kan word deur Jesus Christus, ..."

Hier word die onderskeiding tussen welsynswerk en barmhartigheidsdiens weer baie duidelik. Welsynswerk is menslike hulp wanneer die mens menslike nood sien. Die bron van barmhartigheidsdiens is die genadegawe van God (charis). Hierdie bron bepaal ook die sin van dié diens, nl. danksegging aan God (eucharistia). Tussen charis, charisma en eucharistia is 'n onlosmaaklike teologiese verband. Genadegawe en genade sal ons altyd tot danksegging bring. (eucharistia). (Vgl. II Kor 1:11 en II Kor. 4:15!) Omdat God die genadegawe (Rom. 12:2 en 12:8!) tot hierdie diens verleen, is dit eindelik ook $\mathrm{Hy}$ wat deur diẽ diens van die diakensamp verheerlik word.

\section{Die Creator as „nuwe” vertrekpunt vir die diakonaat van die Wèreldraad van Kerke.}

Wat diakonaat betref, wil die ekumeniese beweging o.a. ook van 'n "Creator" sondermeer vertrek. Die Creator is nog steeds besig om sy doel te bereik, al is dit ook deur die gebruik van heidense en ongelowige magte. Wat dit presies alles vir die diakonaat inhou, is nog nie uitgewerk nie,22) maar daar sal verreikende gevolge wees vir samewerking met ander groepe in die samelewing wat werk in die rigting van sosiale geregtigheid en ook vir die sendingtaak van die kerk.

So dikwels as wat die kerk van vreemde vertrekpunte uitgegaan het vir sy diakonaat, so dikwels het die kerk ook by vreemde plekke uitgekom - m.a.w. nie by sy Heer nie. Dit het eindelik ook daartoe gelei dat die diakonaat in die kerk van verwording tot verval oorgegaan het. Ons kan verwag dat die diakonaat van die Wêreldraad hom nog by vreemde plekke sal bring - ja, reeds gebring het!

21) Codex Vaticanus het hier as lesing to Christo in die plek van to Theó!

-2) The Role of the Diakonia, W.C. of C., Geneva 1966, p. 17. 
Dit gaan in die ampte nooit om 'n ,jus divinum" nie, maar om „donum" van Christus. Die ampte is gawe van Hom wat die wêreld oorwin het. (Kol. 2:15). Los van die gawe Christus en Christus se gawe kan die amp nooit gesien word nie.

\section{BESONDERE EN ALGEMENE AMP.}

Prof. F. J. van Zyl het al herhaaldelik daarop gewys dat die nood wat rondom die besondere amp ontstaan, ons oë altyd weer moet laat oopgaan vir die algemene amp. Die feit dat daar gemeentes is ,waarin daar nie voldoende broeders vir die diakensamp gevind kan word nie", moet as geleentheid gesien word om die hele gemeente onder die besef van sy barmhartigheidstaak te bring.

In die inleiding is gestel dat die vraag na die eintlike opdrag van die diaken nie te vinnig gevra moet word nie. Rondom die verhouding van besondere en algemene amp lê 'n hele reeks vrae. ${ }^{23}$ ) By die „priesterskap van die gelowiges" gaan dit egter nooit om die gemeente wat homself versorg nie. Wanneer ons vra na die fundamentele opdrag van die diaken moet ons die vraag nie so verstaan asof die diaken in die vervulling van sy amp eensaam is nie. Die diakensamp het dan eers sy hele opdrag vervul as hy ook die gemeente tot barmhartigheidsdiens gebring het. Die ,vernuwing" van diakensamp in ons dag sal in die eerste plek inhou dat die diaken die gemeente sal betrek in die praktiese! ${ }^{24}$ ) barmhartigheidsdiens. Die bepaling van die verhouding tussen algemene en besondere amp word in Ef. 4:12 duidelik. Die dienswerk is die gemeente s'n - die ampte is daar om die gemeente toe te rus vir hierdie dienswerk. Die opdrag aan die ampte is dan om die gemeente in lid te trek (katartismos)..$^{25}$ ) Ons moet die dienswerk (diakonia) van die gemeente nie bepərk tot barmhartigheidsdiens nie. Hier is die woord (diakonia) in sy breedste sin te verstaan as elke werksaamheid wat vir die opbou van die liggaam van Christus van belang is. ${ }^{26}$ ) Met hierdie diens word nie alleen die broeders gedien nie, maar Christus. Dat die gemeente in die voorste linie van barmhartigheidsdiens staan, blyk duidelik uit Hand. 2:45 en 4:34. Hier is die hele gemeente telkens ${ }^{2 i}$ ) besig om hulle eie besit tot beskikking van dié te stel wat nie het nie. Die besondere amp van die diaken het hier dus 'n breër

23) A. A. van Ruler, Bijzonder en Algemeen Ambt, Nijkerk 1952.

24) Nie asof barmhartigheidsdiens ooit anders as daadwerklik kan wees nie.

25) Katartismos is eintlik 'n orthopediese term: W. Bauer, W.z. N.T.5 S.V.

26) T.W.z. N.T. II, S. 87.

2:) Die imperfecta is by altwee verse ingeryg. Hier dus geen kommunistiese kapitaalvorming nie; die persoonlike besit van elke gemeentelid staan nou in diens van die Here. 
basis in die opdrag tot barmhartigheid en diens aan elke gelowige. Die weduwees word tot die besondere amp van diaken gekies (katalegein) wat as gelowiges barmhartigheid bewys het. Hulle wat ,getuienis het van goeie werke ... gasvry gewees het, die voete van die heiliges gewas het, verdruktes gehelp en elke goeie werk nagestreef het." (I Tim. 5:10). Inderdaad 'n ryke agtergrond van barmhartigheidsdiens.

Die bevestiging van 'n diaken beteken dus nooit die opheffing van die dienswerk wat eenvoudig uit die gelowige-wees voortvloei nie. Dan eers fungeer die besondere amp reg as hierdeur die gelowige die kans en die moontlikheid gebied word om sy dienswerk te doen; meer nog as dit toerusting hiertoe is. Die besondere amp (soos trouens ook die persoon van die amps. draers) moet in die gemeente wegsyfer. Hiermee wil gesê word dat die beweging van die amp altyd na die gemeente toe moet wees om saam met die gemeente na die Here toe te beweeg.

As wat tot hiertoe oor die besondere amp gesê is, waar is, dan moet die kerk bly wees oor 'n vereniging soos die N.H.S.V. Hier is lidmate op 'n geordende wyse (nie op amptelike vlak nie) met barmhartigheidswerk besig. Hier word gewone lidmate deur die diakonaat meegeneem in die barmhartigheidswerk van die gemeente. Want, dat die diaken amptelik besig is met die barmhartigheidsdiens beteken juis dat hy nie „amptenaaragtig" alles in eie hande sal wil hou nie. Dit is juis sy roeping dat hy sy werk uit sy hande sal uitgee. Dan wanneer hy die gemeente aansteek tot barmhartigheid het hy sy werk reg gedoen. Die besondere amp (ook in sy mees amptelike vorms) wil aan die priesterskap van die gelowiges geen afbreuk doen nie. ${ }^{28}$ ) Die besondere amp is juis ten dienste van die priesterskap van die gelowiges. Daarom kan dit ook in die verhouding van N.H.S.V. en diakensamp nooit daarom gaan of die N.H.S.V. die werk van die diaken uit die hand neem nie. Inteendeel, die diaken moet haar meer werk (en middele!) in die hand gee. Hy moet sy amp so vervul dat die hele gemeente ,aangesteek" word tot barmhartigheidsdiens. Dat die N.H.S.V. as ,gewone" lidmate barmhartigheidswerk sal doen, is nie alleen Bybelshoudbaar nie, maar Bybelsnoodwendig. Ook die Kerkwet ${ }^{20}$ ) wil dit duidelik stel dat die diaken nie eensaam is in die barmhartigheidsdiens nie. Ter vervulling van die priesterskap van die gelowiges word die lidmate van de kerk geroep om die ampsdraers by te staan in diens van die kerk, en naas hulle werksaam te wees in die

29) A. A. van Ruler, Bijzonder en Algemeen Ambt, P. 51.

$\left.{ }^{29}\right)$ Kerkwet van die Ned. Herv. Kerk van Afrika, VII. 
diakonaat o.a. Dat die gemeente tot barmhartigheid geroep is, blyk duidelik uit Artikel 172 van die kerkwet. Omdat Art. 172 as opskrif "Arbeidsveld vir die diakens" het, lyk dit asof die gemeente nou sy werk aan die diaken oorgegee het. (Veral in die lig van Art. 173, 1). Dat die barmhartigheidsdiens roeping van die gelowiges is, word deur die Kerkorde van die Nederlandse Hervormde Kerk duideliker gestel:

„De gemeente, in al haar leden geroepen tot de dienst der barmhartigheid, beantwoordt, onder de leiding of door de arbeid van de diakenen, aan deze roeping in het diakonaat"." ")

En verder:

„De diaken bevorderen door hun voorligting en leiding, dat de gemeenteleden gehoor geven aan hun diakonale roeping." ${ }^{31}$ )

Wat die diakonaat betref, kom die priesterskap van die gelowiges duideliker tot uitdrukking in die Kerkorde van die Nederlandse Hervormde Kerk as in ons eie kerkwet. Artikel 172 van ons eie kerkwet sal duideliker herformuleer moet word.

As slot moet die opmerking gemaak word dat nóg die diaken nóg 'n vereniging die gelowige sy opdrag tot bramhartigheid ontneem. Die gelowige kan hom ook nie van die barmhartigheidsdiens loskoop deur 'n paar geldstukkies in die armbeurs te gooi nie.

\section{NU-TESTAMENTIESE FUNDERING VAN DIE DIAKENS-} AMP.

\section{A. ENKELE BEGRIPPE RONDOM DIE BARMHARTIGHEIDS- DIENS.}

\section{Diakonein.}

Die begrip diakonein (om kelnerwerk te doen) het teenoor die ander woorde wat vir, dien' gebruik word die besondere betekenisaspek dat dit in die eerste plek persoonlike liefdesdiens wil aandui. In die tweede plek wil diakonein sê dat ons hier 'n nederige werk het, (kelnerswerk). Vir die Griek is hierdie soort dien iets minderwaardigs. Die wyse en vrye mens kan nie in 'n nederige persoonlike diens staan nie. Alleen diens aan die staat het positiewe betekenis.

Vir die Jood is dienswerk nie vernederend nie. Tereg word gesien dat die opdrag in Lev. 19:18: . . ., ,jy moet jou naaste liefhê soos jouself" ook diens aan die naaste insluit. Die vroomheid

\footnotetext{
30) Kerkorde der Nedl. Herv. Kerk. Ord. 15, Art. I. Elke lidmaat is geroep tot barmhartigheidsdiens maar só (1) dat dit roeping van die gemeente is en (2) dat algemene priesterskap en besondere amp nie identies is nie.

:i) Kerkorde., Ord. 15, Art. 2.
} 
van die Fariseërs, wat sterk skeiding maak tussen regverdiges en onregverdiges, verswak die besef van liefdesdiens teenoor die naaste. Nou word barmhartigheid selektief gedoen (die Samaritaan moet maar bly lê,) en word dit tot verdienstelike werk.

Die begrip diakonein het ók wanneer dit teologies gebruik word, 'n algemene, breër betekenis, alhoewel hierdie breër betekenis altyd die aspekte van persoonlikheid en nederigheid behou. ${ }^{32}$ ) Hierdie algemene betekenis kry ons in I Kor. 12: $4{ }^{33}$ ) en Ef. 4:12. In Ef. 4:12 staan naas die "dienswerk" (eis ergon diakonias) "tot opbouing van die liggaam van Christus" (eis oikodomēn tou sómatos tou Christou) as verklarende ekwivalent. Verder vind ons hierdie breër betekenis ook in Hand. 20:24; II Kor. 6:4; 11:23; Ef. 3:7; Kol. 1:25; I Kor. 16:15.

As besondere barmhartigheidsdiens vind ons die begrip in Matt. 25:44; Hand. 6:2; Rom. 15:25; II Kor. 8:41. Hierdie breër betekenis van die begrip diakonein sal ons daarvan bewaar om die barmhartigheidsdiens van die kerk as die enigste of eintlike diens te beskou. $K$. Barth het daarop gewys dat die breër en die meer besondere betekenis van die begrip diakonein nie geïsoleerd kan staan nie. Ons moet die breër en meer algemene betekenis nie uit die oog verloor wanneer ons met die meer besondere betekenis besig is nie. Watter besondere doen van die gemeente sny nie die breër diens nie? Watter besondere diens is nie met die breër diens verbind nie?

En omgekeerd watte: algemene diens van die gemeente sal nie die karakter van die barmhartigheid dra nie. ${ }^{34}$ )

Waarom sou die begrip diakonein naderhand die eintlike begrip word om die barmhartigheidsdiens te omskryf? Die antwoord sal ons moet soek (1) in die rigting van die algemene geskiktheid daartoe omdat hierdie begrip van huis uit 'n nederige en persoonlike diens aangedui het. (2) Jesus Christus self gee na 'n omskrywing van die inhoud van die barmhartigheidsdiens van die gelowiges, aan hierdie diens die naam diakonein (diēkonēsamen Matt. 25:44).

\section{Ptóchos.}

By die fundering van die diakensamp word Lukas 4:18, 19 en 21 dikwels gebruik.

"Die Gees van die Here is op My omdat Hy My gesalf het om die evangelie aan die armes te bring."

32) Hierdie breër en besondere betekenis kry ons al by die nie-teologiese gebruik van die begrip: breër bv. Matt. $22: 13$ en besonder bv. Luk. 17:8; Joh. 2:5; Mark. 15:41.

33) H. Conzelmann, Erster Korintherbrief, Meyer Kommentar V. Abt, Göttingen 1969, S. 245.

34) K. Barth, Kirchliche Dogmatik, IV/3 ii, S. 1020. 
Die uitleg van die woord ptóchos sal vir hierdie gedeelte beslissend wees in hierdie verband.

\section{(a) Agtergrond van die begrip.}

Vir die Grieke beteken ptóchos bedelarm. Die arme se absolute besitloosheid dwing hom om te bedel. Gee van aalmoese aan die armes is geen deug nie. ,Goeddoen' is nie om aalmoese te gee nie, maar om diens aan die staat te lewer. Die begrip arm in die Ou Testament wys op die man wat in 'n afhanklike posisie is vanweë onterwing of op die man wat liggaamlik swak of onbeduidend is. In die Ou Testament kom ,arm' dikwels in 'n godsdienstige betekenis van deemoedig en vroom voor. Die ,armes word daarom maklik met die Godsvolk geïdentifiseer. Amos 2:6; Jes. 10:2; Jes. $3: 15 ; 14: 32$.

Vanuit sy Ou Testamentiese verband het ons in Luñ. 4:18 nie eintlik met materiële armes te doen nie, maar met die volk van God wat verontreg en verarm is deur verdrukking. Hierdie ellendiges hoop op God en verwag van Hom hulle verlossing. Jesus verkondig die dag in die sinagoge dat God se eindtydelike ingryping in die lot van sy ellendige volk in Hom werklikheid geword het. Hy is die Messias! Ptóchos het hier die betekenis: in gelowige afhanklikheid op God hoop in hierdie ellende waarin ons sy volk, verkeer. Ons het hier in die eerste plek nie met 'n sosiale terminologie te doen nie, maar met 'n godsdienstige terminologie. Ptóchos moet hier nie teen die agtergrond van sy griekse etimologie verstaan word nie maar teen die agtergrond van die Ou Testamentiese begrip arm.

\section{Koinónia.}

Vanuit sy algemene betekenis het koinónia 'n sterk sakrale aspek: gemeenskap hê aan die gode. So gebruik Paulus ook veral die begrip. Koinona is gemeenskap met Christus (I Kor. 1:9). Hierdie gemeenskap word deur die geloof in die Nagmaal beleef en werklikheid as gemeenskap aan Christus en aan al sy goedere. (I Kor. 10:16 vv.) Maar die Christusgemeenskap word ook christengemeenskap (I Kor. 10:17 hen sóma). Hierdie christengemeenskap is altyd verbonde aan die Christusgemeenskap. Hierdie verband is die Heilige Gees (koinónia tou hagiou pneumatos!) Die verband tussen Christus en christen is dus nie die van voorbeeld sondermeer nie en die band tussen christen en medemens is nie 'n sosiologiese sondermeer nie, maar gemeenskaplike verbintenis aan Christus deur die Heilige Gees. Die gemeenskap tussen christen en medemens moet dus altyd teen die agtergrond van gemeenskap met Christus deur die Heilige Gees gesien word. 
As ons koinónia só verstaan, sal dit van twee dwalinge rondom die barmhartigheidsdiens behoed.

(1) Van die dwaling van Rome wat barmhartigheid tot verdienstelike goeie werk wil verhef.

(2) Die barmhartigheid wat ons vandag so dikwels vind as blote sosiologiese en politieke aangeleentheid asof dit in die evangelie eintlik om die sosiologiese en politieke gaan.

Die christengemeenskap ontspring as ,gemeenskap deur die Heilige Gees" by Christus en is daarom ook na Hom op pad. Die gemeenskap van die gelowiges het wel 'n sosiologiese en politieke (of watter menslike verhouding ookal) betrokkenheid, maar hierdie dinge is nooit die einddoel van die christengemeenskap nie.

Só is die kollekte vir die heiliges in Jerusalem nie 'n blote geldelike of welsyns aangeleentheid nie, maar uitdrukking van die gemeenskap wat tussen die gelowiges in Christus bestaan (II Kor. 8:4). Hierdie gemeenskap het as grond hulle oorgawe aan Christus en bestaan dan in 'n nederige en persoonlike diens aan die heiliges. Die bron van hulle ryke mildadigheid is hulle oorvloedige blydskap. (I Kor. 8:2; Gal. 6:6; en Rom. 15:27). Gemeenskap in die Nuwe Testament vloei altyd uit die evangelie voort of het ten doel om die evangelie voort te laat vloei. (Filip. 4:15). Hierom is dit gemeenskap aan die evangelie (Filip. 1:5).

\section{Leitourgein.}

Paulus gebruik die woord vier maal om die diakonaat te beskrywe. (Rom. 15:27; II Kor. 9:12; Filip. 2:30; Filip. 2:25). Algemeen het die woord die betekenis van volksdiens en wel so dat dit 'n diens is wat aan die volk (as politiese gemeenskap) bewys word wat eintlik taak van die gemeenskap self is..$^{35}$ ) Die begrip het dus 'n besonder sterk tegniese karakter.

Naas sy tegnies-politieke karakter kan die begrip ook kulties gebruik word.

Vanuit die algemene betekenis van leitourgein kry ons vier gedeeltes besondere betekenis. In twee gevalle (Rom. 15:27, II Kor. 9:12) is die gemeente besig met barmhartigheidswerk. In onderskeid van diakonein wil leitourgein beklemtoon dat hierdie diens amptelik d.w.s. omskrywe is en as sodanig 'n „verpligte' diens is. Ons sal sien dat hierdie 'n dankbaarheids- en vreugdeverpligting is.

Die twee gedeeltes in Filipense (Filip. 2:30 en 2:25) maak dit duidelik dat die barmhartigheidsdiens eintlik die gemeente se taak is en dat Epafroditus hierdie taak nou vir die gemeente

35) T.W.z.N.T. Band IV, S.V. 
volvoer. Vanuit die sterk tegniese agtergrond (d.w.s. plaasvervangende, omskrewe en verpligte diens) van die begrip sal mens moet sê dat ons in Epafroditus met 'n diaken van Filippi te doen het.

\section{Eleos.}

$\mathrm{Na}$ 'n ondersoek van die begrip barmhartigheid het dit geblyk dat die beste vertrekpunt vir die probleemstelling rondom die begrip Matt. 23:23 is.

„... en die swaarste van die wet laat julle na: die reg en die barmhartigheid en die trou."

Die volgende vrae kom na vore uit hierdie vers:

(1) Wat is die oorsprong van hiérdié barmhartigheid?

(2) Is daar na betekenis 'n verband tussen reg, barmhartigheid en trou? Het ons hier met begrippe te doen wat langsmekaar of agtermekaar staan?

(3) Wil Jesus teenoor die kasuistiese godsdiens van die Fariseërs wat 'n oorwegende vertikale rigting het en oor die medemens nie veel bekommer nie nou 'n oorwegende horisontale godsdiens stel? Stel Jesus hierteenoor die tiendes wat na God gaan, die barmhartigheid wat aan die mens gegee word?

(4) Hoe moet ons dit verstaan dat die barmhartigheid die ,swaarste van wet' is?

(5) Is barmhartigheid 'n ,gevoel'?

Van bepalende betekenis vir die begrip eleos is dat die barmhartigheid van God in Christus openbaar is. Gods barmhartigheid is sy "heilshistories-eskatologiese daad in Christus". ${ }^{30}$ ) In Christus staan God se geregtigheid en barmhartigheid langsmekaar. Hierdie barmhartigheid van God het in die eerste plek ons sondenood voor oë (o.a. Rom. 11:30-32, 15:8, I Petr. 2:10), maar sluit ook Gods barmhartigheid oor ons liggaamlike kwelling in. So roep die kranke tot Jesus: Wees my barmhartig! (eleēson me, vgl. Filip. 2:28; Mark. 5:19!)

In die Griekse spraakgebruik is barmhartigheid 'n gevoel van jammerte vir iemand wat teenspoed het. Hierdie jammergevoel is ook gemeng met die vrees dat so 'n ramp mens ook sal kan tref. Logies is dit so dat die barmhartigheid nie langs die geregtigheid kan staan nie. Die medelye sal tot gevolg hê dat die oë vir die reg gesluit moet word. Hierom is barmhartigheid vir die Stoa 'n krankheid en die wyse onwaardig.

Die ou testamentiese begrip hesed is sterk bepalend vir die inhoudsbepaling van die begrip barmhartigheid. Hier is barmhartigheid nie soseer 'n gesindheid nie, maar 'n verhouding, 'n

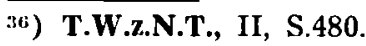


hulpdaad wat uit getrouheid spruit. Dit is verhouding wat uit die verbond voortvloei. As sodanig is die begrip altyd verbind met die begrippe mišpat, (beslissing/regspraak/ 'n regverdige beslissing) Hos. 12:7; Mig. 6:8; Jer. 9:24; Sag. 7:9; Ps. 101:1 en șidakah (geregtigheid), Ps. 36:11; 40:11; 43:11.

Vanuit sy heilshistories-eskatologiese gebruik, en sy bepaaldwees deur die begrip hesed (verbondstrou?) is barmhartigheid daad van helpende trou.

In die $\mathrm{Ou}$ Testament word die begrip barmhartigheid veral gebruik in die vertikale verhouding, maar só dat dit op God se verbondstrou wys. In die Nuwe Testament oorheers hierdie betekenis die begrip ook teologies. Maar wat die gebruik betref, het die begrip hier 'n sterk horisontale rigting as verhouding tussen gelowiges. Matt. 9:13; 12:7. Dit is opmerklik dat in Matt. 12:7 barmhartigheid juis regverdigheid beteken; verbasend is dit natuurlik nie, want ons het gesien dat die begrip eerder vanuit 'n ,juridiese" sin verstaan moet word.

Barmhartigheid is dus nie soseer die antwoord op 'n noodsituasie wat voorhande is nie, maar dit is antwoord op die gawe en eis van God. Die motief tot barmhartigheid is die barmhartigheid van God.

Die vertikale en horisontale aspekte van die begrip kan nooit geskei word nie al het ons met 'n besondere aspek te doen. So bv. word in Matt. 5:7 onder ellende nie alleen die uiterlike nood bedoel nie, maar veral die nood van sonde en skuld.

Wanneer barmhartigheid inhou dat skuld vergewe word, betaal die vergewer die skuld. Ons het hier nie met 'n „die oë toehou" te doen nie, maar ook nie met 'n kondonering van die skuld nie.

Ons het gesien dat God se barmhartigheid motief vir ons eie barmhartigheid is. Dit moet so verstaan word dat God se barmhartigheid voor gaan. Ons bewys nie barmhartigheid om daardeur van God barmhartigheid te ontvang nie. Maar, die besondere formulering van Matt. 5:7 en ook die vyfde bede van die „Onse Vader" wil dit duidelik stel dat die barmhartigheid opdrag van God is. Die begrip eleos onderstreep dié feit dat alhoewel die barmhartigheidsdiens 'n nederige werk is, die barmhartigheid nie onbelangrik is nie, maar as opdrag van God 'n belangrike taak is wat ons ten volle ernstig moet opneem.

\section{B. DIE GESKIEDENIS VAN DIE DIAKENSAMP IN DIE NUWE TESTAMENT.}

As ons die Nuwe Testament verstaan as heilsgeskiedenis sal ons ook moet aanvaar dat die amp van die diaken 'n geskiedenis gehad het. Die amp van die diaken het nie eensklaps volledig en 
netjies uitgewerk gereed in die gemeente gelê nie. Dit is ook duidelik dat die barmhartigheidsdiens van die kerk nie eers toe begin het toe die diakensamp volledig gestalte gekry het nie.

Die amp van die Nuwe Testament moet eerder aan sy, diens' en inhoud geken word as aan 'n spesifieke benaming of omskrywing. Die benaming vir besondere dienste het eers met die verloop van tyd gekristaliseer (aanvanklik word episkopoi en presbyteroi nog sinoniem gebruik bv. Hand. 20). Dat die inhoud van die ampte hierom nog nie duidelik omlyn was nie, is onwaar. Oor die diens en inhoud van die besondere ampte was geen onduidelikheid nie, al is üie amp met verskillende woorde omskryf. Dit is ook waar van die diakensamp. Verskillende begrippe wat gebruik word om die diakonaat te omskrywe dra nie by tot die vloeibaarheid van die inhoud van die amp nie, inteendeel, dit dien tot duideliker omlyning van die diens, (bv. diakonein en leitourgein). Selfs ook wanneer die inhoud van die diakensamp groei, bly hierdie inhoud steeds aan die kernopdrag getrou. Ons kan sê die groei in inhoud beteken dat die diakonaat net meer fasette bykry. Die kernopdrag self word in die Nuwe Testament egter nooit uitgebrei nie. Dit is eers 'n latere afwyking.

Dit is tragies dat die vreemde belading van die diakensamp by Rome en by die Church of England eindelik tot die praktiese verdwyning van die diakensamp gèlei het. Eers word die amp van die diaken gelaai sodat hy naderhand 'n faktotum in die kerk is. Maar al gou blyk dit dat hy te handig is en 'n bedreiging vir die hiërargie en ander ampte word. Dan word sy amp weer sistematies ontlaai totdat daar vandag vir die diaken in Rome net enkele liturgiese funksies rondom die Mis oorbly. Maar omdat daar so min diakens is, word hierdie diens dan maar deur die priester verrig. ${ }^{37}$ ) Die afwyking rondom die diakensamp moet egter gesien word in die lig van die breër afwyking vanaf die derde eeu in die kerk toe erediens offerdiens geword het en die liturgie so uitgebreid geraak het, dat die biskop en priester dit onmoontlik alleen kon behartig. By die diaken se kernopdrag is toe eiemagtig, a.g.v. die verleentheid van die kerk, ander opdragte bygevoeg. Toe die situasie dreig om hand uit te ruk, is die oplossing gevind in die radikale subordinering van die diaken aan die ander ampte. Die geskiedenis het getoon dat toe die amp van die diaken op 'n eiesinnige manier en vreemd aan die Bybelse opdrag gevul is, dit vir die amp dié rampspoedige gevolg gehad het dat dit prakties verdwyn het. In die Roomse Kerk het die hoofdiaken o.a. die eerste administratiewe beampte van die biskop

3i) Oxfort Clas. Dict. of the Christ. Church, S.V. 
geword. So het die diaken dan ook 'n noue verbintenis met die Pous gehad en hierdeur besonder baie invloed en mag gekry. Hy was nou so besig met een van sy vele take in die erediens (as voorsinger of om leiding te gee by die gebede) of met die administrasie dat van die barmhartigheidstaak weinig of niks oorgebly het nie. Nou het hy egter 'n bedreiging vir die priester geword en is in 'n reeks Sinodes al sy opgelegde pligte hom weer ontneem (vanaf 633). Na die Middeleeue is die diakensamp bloot ' $n$ trap in die voorbereiding tot die priesterskap. Eers het die inhoud van die amp verdwyn toe het die amp self prakties verdwyn.

Die amp van die diaken se verval en verdwyning in Rome is 'n verdere voorbeeld van die sterk band tussen leer en lewe in die kerk. Die verval van die diakensamp by Rome hang saam met die verwording van die erediens tot offerdiens. Die offer het alles nou oorheers en alle ampte opgeëis. Die Kerk, en daarom ook die diaken, het nou geen werk of belang buite die offerdiens gehad nie.

\section{Mattheus 25:31-46 as omskrywing van die diakonaat.}

Jesus se omskrywing van die inhoud van die barmhartigheidsdiens lewer geen besondere moeilikhede nie. Die sin van hierdie gedeelte sal afhang van die uitleg wat aan vers 40 gegee word. Wie is "hierdie broeders van my"? Hoe moet ons "hierdie geringstes" verstaan? Hierdie gedeeltes word baie verskillend uitgelê..$^{39}$ )

(a) Hier is nie van die christendom sprake nie, maar word die maatstaf genoem waarmee Jesus almal meet, of hulle Hom ken of nie.

(b) Hier is van die dissipels sprake. Die woord kleinstes (elachistos) is bepalend vir die verstaan van hierdie gedeelte.

Mattheus gee aan ons vier spreuke deur oor ,hierdie kleines". ${ }^{39}$ ) (Matt. 10:42; 18:6; 18:10; 18:14). Nêrens is hier eintlik sprake van kinders nie. Uit al hierdie gedeeltes is dit duidelik dat Jesus "hierdie kleines" in sy besondere beskerming neem. Teen die agtergrond van "hierdie kleines" in Mattheus kan ons 25:40 en 25:45 alleen verstaan as die dissipels van Jesus Christus. Juis as navolgers van Jesus Christus verkeer hulle in ellende. Die regverdige is hy wat "hierdie kleines" "net 'n beker koue water laat drink, omdat hy 'n dissipel is" (Matt. 10:42). Die bepalende is hier dus nie die nood nie, maar die feit dat 'n gelowige in nood verkeer. Barmhartigheid is dus om jou te vereenselwig

38) A. Schlätter, Der Evangelist Matthëus, Stuttgart 1959, S. 725.

39) Elke keer kry ons hierdie kleines (touton) ook by Matt. 25:40 en 25:45. Die aanwysende v.nw. dui daarop dat Jesus na die "kleines" of "geringstes" toe wys. 
met 'n dissipel wat in nood verkrer omdat hy 'n dissipel is. Dit is juis hierdie kleinwees wat ,identifikasie” tussen Jesus Christus en "hierdie kleines meebring. Soos Jesus is hulle diens 'n nederig? gehoorsaamheid en 'n totale ourgawe. Hulle eie belange staan nie voorop nie. Juis omdat hulle in Jesus Christus se diens staan, is hulle in groot ellende. Omdat hulle syne "') is, is die diens aan hulle diens aan Jesus self. Hier bind geloof en liefde Here en „kleines”. (Matt. 20:28).

\section{Die wonderwerke van Jesus.}

Die wonders van die Here het veral 'n barmhartigheidskenmerk. Lit is of genesingswonders of spysiging van hulle wat honger is. Hoe ons die wonders verstaan, sal medebepalend wees vir die sin van die diakonaat. Staan die wonders selfstandig? Met ander woorde, moet ons hier stilstaan asof ons genoeg gesien het? En, wil die Here hierdeur tot die geluof lei? Joh. 5 kan as voorbeeld geneem word tot beantwoording van hierdie probleem.

Ons moet die wonders sien as teken van die koninkryk van God. Hier gryp God in Jesus Christus kragvol in in die lewe van mense. Hier het ons teken dat die koninkryk van God in Jesus Christus aangebreek het. Tussen sien $\in \mathbf{n}$ glo is egter nie 'n noodwendige verband nie.") Die gelowige is die een wat "my woord hoor en Hom glo wat My gestuur het". (Joh. 5:24). Die sien van wonders is nie noodwendig om in Jesus te glo nie. By die wonders kan ons nie stilstaan asof ons nou genoeg gesien het nie. Die vader sal aan die Seun "groter werke as hierdie" toon. (Joh. $5: 20$ ). Jesus Christus wil hê dat ons by die groter ,wonder' van die kruis en opstanding sal stilstaan.

In die lig van Joh. 5 sal ons Jesus se bekommernis oor die mense as 'n totale moet beskryf. Hy is bekommerd oor hulle liggaamlike en ,geestelike" nood nl. hulle sonde. Maar in sy kommer is daar onderskeiding. Die aksent val op die sondenood $^{\prime 2}$ ) Dit sal ons daarvan bewaar om die diakonaat as die enigste en eintlike werk van die kerk te sien, of as die belangrikste, of as 'n minderwaardige werk wat ook maar gelaat kan word.

\section{Die barmhartigheid van Jesus en sy dissipels.}

Jesus en sy dissipels was gewoond om uit hulle gemeenskaplike beurs aan die armes te gee. Toe Jesus Judas Iskariot met die stukkie aangewys het, het party dissipels dit so verstaan dat

411) J. Schniewind, Matthëus, N.T.D. 248, by Matt. 25:40-45.

41) C. K. Barrett, The Gospel According to St. John, London 1955, by Joh. $5: 19-47$.

12) Só verstaan die apostels dit ook. Hand. 6:2: „Dit is nie reg dat ons die Woord van God nalaat om die tafels te bedien nie". 
Judas, ,iets aan die armes moes gee". (Joh. 13:29). Dit was iets waarmee hulle so vertroud was dat hulle die inhoud toe baie maklik kon gee aan wat vir hulle onduidelik gewees het.

Ook die verwyt van die dissipels aan die vrou wat Jesus salf dat dit 'n verkwisting is, ,want hierdie salf kon duur verkoop en aan die armes gegee geword het", dui daarop dat hulle gewoond was om die armes te versorg. (Matt. 26:9).

\section{Handelinge 6.}

Vroeg in die geskiedenis van die kerk het dit duidelik geword dat die apostels nie al hulle verantwoordelikhede alleen kon behartig nie. Daar moes verwaarlosing na die een of ander kant toe plaasvind. Die apostels het toe eerder die tafeldiens verwaar. loos omdat hulle nie die Wourd van God wou nalaat nie. Maar die tafeldiens kon ook nie nagelaat word nie. Op aandrang van die apostels is toe manne gekies en „oor hierdie nodige saak" aangestel. (Hand. 6:3). Hierdie manne moes van goeie getuienis wees, vol van die Heilige Gees en wysheid. Hierop gaan die gemeente oor tot die verkiesing van manne wat die verantwoordelikheid kon aanvaar vir die noodsaaklike diens van die tafels, terwyl die apostels sou volhard in die gebed en die bediening van die Woord. Na die verkiesing word daar gebid en word die hande hulle opgelê deur die apostels.

Hier het ons die oordrag van 'n spesifieke funksie van die apostels aan ander mense wat hierdie oorgedraagde funksie nou amptelik vervul (verkies deur die gemeente, vir hulle gebid en die hande opgelê.) As amptelike werk word die versorging van die weduwees nou aan besondere manne opgedra. Dit moet ons nie verbaas dat hierdie manne hulle nie uitsluitlik met die barmhartigheidsdiens besig hou nie. Hulle het hiertoe 'n besondere opdrag gehad maar het hulle nie uitsluitlik daarmee besig gehou nie. Alhoewel ons hier die wortel van die diakensamp het, is die amp hier nog nie volledig uitgewerk nie. Juis omdat hierdie manne vol van geloof en krag gewees het, is daar met hulle geredetwis. (Hand. 6:9). Juis hierom stuur 'n engel van die Here hulle ook om die evangelie op eensame paaie te gaan verkondig. (Hand. 8:26).

Hierdie opdrag kry hulle nie omdat die tafeldiens aan hulle opgedra is nie, maar omdat hulle besonder begaafde mense gewees het. Vanuit hierdie ander opdragte kan mens dus nooit beweer dat hulle nie diakens gewees het nie. Vanuit hulle eintlike opdrag gaan ons hulle nie sondermeer diakens noem nie. (Handelinge doen dit nie). Hulle besondere opdrag was 
egter in die rigting van die diakensamp: hulle is oor die noodsaaklike tafeldiens aangestel (kathistēmi). ${ }^{\prime \prime}$ ) En dit is vir die geskiedenis van die diakensamp belangrik nl. dat hulle 'n besondere opdrag gehad het en dat hierdie opdrag rondom die barmhartigheidsdiens gelê het. Met betrekking tot hulle amp is hulle ander werksaamhede ,toevallig". Hulle het geen ander besondere opdrag van die gemeente gehad naas hulle barmhartigheidsdiens nie en hulle ander werksaamhede was nie deel van hulle besondere opdrag nie. Alhoewel die amp 'n geskiedenis sou hê vanuit Handelinge 6 , is die diens wat an dié manne opgedra is, reeds hier streng afgebaken.

Rondom Handelinge 6 is daar veral twee sake wat duidelik word.

1. Ons het hier met die barmhartigheidsdiens te doen. Die oorsig het immers gekom by die dagelikse versorging. (en tē diakonia! tē kathēmerinē).

2. Ons het hier met die amptelike barmhartigheidsdiens te doen. Eers is daar uitgekyk (episkeptomein). Die verkiesing word dus deur 'n ondersoek vooraf gegaan. Vgl. dokimazein in I Kor. 16:4 (goedgekeurdes!) $\mathrm{Na}$ die ondersoek het die verkiesing plaasgevind (eklegein, 6:5). En na die verkiesing is hulle die hande opgelê. (Hand. 6:6).

\section{Die diensbetoning aan die heiliges.}

Uit Galasiërs 2 blyk dit dat toe die arbeidsveld tussen die apostels in Jerusalem en Paulus verdeel is en Paulus na die heidene sou gaan, is daar net een voorwaarde aan Paulus gestel: ,alleen moes ons aan die armes dink ....' (Gal. 2:10). Paulus se opmerking hierop ,wat ek my juis ook beywer het om te doen", word uit die geskiedenis duidelik bevestig. Paulus noem hierdie „dink aan die armes”, diakonia. Hierdie diensbetoning (diakonia) is nie armversorging sondermeer nie. Ons het reeds gesien dat dit verbonde was aan die ooreenkoms wat bereik is toe Paulus na die heidene toe sou gaan. Hier word dit duidelik dat die barmhartigheid altyd die evangelie as voorwerp het. Die heidene is skuldenaars van die gemeente in Jerusalem omdat hulle van Jerusalem die evangelie ontvang het.

„Want as die heidene deel gekry het aan hulle geestelike voorregte, is hulle ook verskuldig om hulle met stoflike goedere te dien". (Rom. 15:27 vgl. II Kor. 8:14).

Hierdie diensbetoning is uitdrukking van die heidene se vreugde oor die evangelie. Nood is dus nie die oorsprong en sin van

43) Kathistémi het 'n sterk amptelike kleur. Luk. 12:14: . . „wie het My as 'n regter of deler oor julle aangestel". 
hierdie diensbetoning nie, maar die evangelie. Nood speel hier nie die eerste rol nie, maar vreugde en dankbaarheid. Omdat genade (charis) oorsprong is van hierdie diensbetoning (II Kor. 8:1), daarom kan hierdie diens as „ryke mildadigheid" plaasvind te midde van baie beproewing en verdrukking ten spyte van „diepe armoede". (II Kor. 8:2).

Die beweging en spanning by barmhartigheid is dus baie anders as by welsyn. By welsyn is die beweging van hoë besit na lae besit. (Langenhoven: 'n afknypseltjie uit weelde vir gebrek). By diensbetoning is die beweging van hoë dankbaarheid af en speel besitspanning geen rol nie, sodat die ,normale' beweging selfs omgekeer word.

Wat die insameling ${ }^{44}$ ) vir hierdie diensbetoning betref, het die apostel algemeen gereël dat dit op die eerste dag van die week gebeur en dat die gemeente dan goedgekeurde manne ${ }^{45}$ ) met die gawe na Jerusalem stuur. (I Kor. 16:1-4). Dat dit hier nie om 'n ,gewone' insameling gaan nie, word duidelik as Paulus hierdie diens 'n gawe (charis) noem. (I Kor. 16:4). Hierdie is dus welwillendheid wat voortvloei uit God se genade en het ook die sin om diensbetoning ${ }^{46}$ ) aan die gemeente in Jerusalem, maar veral dankbetoning (eucharistia) aan God te wees. (Vgl. II Kor. 9:12).

\section{Sommige van Paulus se reisgenote.}

\section{(a) Epafroditus.}

Terwyl die apostel Paulus die evangelie verkondig het, het hy nie pal tente gemaak om in sy eie lewensonderhoud te voorsien nie. Soms het dit wel gebeur. As Paulus die ouderlinge van Efese toespreek sê hy vir hulle: „.. . maar julle weet self dat hierdie hande voorsien het in die behoeftes van my en die wat by my was". (Hand. 20:34). Die normale was egter dat gemeentes in die apostel se behoeftes voorsien het. Hy wil dat die gemeente van Rome hom voorthelp na Spanje. (Rom. 15:24). Die gemeente van Filippi stuur meer as een maal iets vir sy behoefte na Thessalonika. (Filip. 4:16). Die nood van die apostel het dikwels egter uit sy gevangenisskap voortgespruit. Dan het die gemeentes in barmhartigheid die apostel versorg. (Heb. 10:34).

Die gemeente in Filippi stuur Epafroditus met 'n milde gawe en met die opdrag om Paulus te versorg. Paulus noem hom ,,julle

14) Logeia is 'n geldinsameling vir watter doel ookal. W. Bauer, Wörterbuch., S.V.

4.5) Diakens? Na inhoud wel; (dokimazein) (I Kor. 6:4; II Kor. 8:22) geskik ag.

wi) 'n Goeie vertaling vir hé diakonia tès leitourgias (II Kor. 9:12) is moeilik; dalk „die bediening van hierdie diens"? 
afgevaardigde (apostolos) en bedienaar (leituurgos) van my b乞hoefte". (Filip. 2:25 - vir leitourgos vgl. Rom. 15:27!) Die gemeente stuur Epafroditus amptelik as versorger van Paulus en gee hom ook die middele om die apostel mee te versorg. Paulus sê dan ook dat Epafroditus besig was met die ,werk van Christus" terwyl hy met diensbetoning (leitourgia) namens die gemeente besig was. (Filip. 2:30).

Paulus noem nooit uitdruklik dat Epafroditus diaken gewees het nie, maar hy noem hom leitourgos!

Vanuit die diakenswerk van die gemeente en Epafroditus kry die opskrif van die Filippensebrief besondere betekenis as Paulus net hier naas die ouderlinge ook die diakens noem. Die diakens van die gemeente het Paulus op 'n besondere manier versorg en hieroor is hy dankbaar en meld hy hulle ook in dankbaarheid. Twee argumente word veral na vore gebring om te bewys dat ons hier nie eintlik met die diakensamp as sodanig te doen het nie. (1) Daar word tussen charisma en amp onderskei. Die charisma is dan die vry-Geestelike en die amp dan die meer geordend-institutêre. As ons die charismatiese uit die amp wil lig, sal daar van die amp in die vroeë gemeente (en ook vandag!) niks oorbly nie, want genadiglik (charismaties) beteken juis Geestelik. Genadegawe is Geestesgawe. (I Kor. 12:4). (2) Ons moet die ouderlinge en diakens van Filip. 1 eerder in 'n ekonomiese sin sien as in 'n amptelike. Daar word met ander woorde onderskei tussen die-werk-van-'n-diaken-doen en die amp-vandiaken-beklee. Dit staan vas dat die ampte in die Nuwe Testament 'n ekonomiese karakter gehad het, (dit behoort vandag ook nog so te wees!) Ons het hier beslis te doen met die leiers van die gemeente in Filippi. Die amp van diaken bekle? is onlosmaaklik verbind met die werk van 'n diaken doen, d.w.s. die ekonomiese karakter van die amp.

Die ampte van die ou gemeente het nooit op 'n losse voet gestaan nie. Epafroditus is amptelik as diaken na Paulus gestuur om hom te versorg; hy het m.a.w. 'n besondere opdrag daartoe gehad. Ons het in sy persoon met 'n leier uit die gemeente van Filippi te doen; hy was leier wat die versorgingswerk betref.

\section{(b) Tichikus.}

Paulus noem hom in Ef. 6:21; Kol. 4:7 'n getroue dienaar (diakonos). In die lig van Epafroditus is dit waarskynlik dat ons hier ook te doen het met 'n diaken uit Asië (Hand. 20:4) wat as reisgenoot en hulp vir Paulus moes dien. Dit is opmerklik dat hy Paulus vergesel na Jerusalem waar Paulus die liefdegawe aan die heiliges gaan oorbring. Paulus stuur hom na die gemeente van 
Efesc om die brief oor te bring en om veral die gemcente te trcos oor die toestand van die apostel. Hy gaan amptslik verslag doen aan die gemeente oor die welstand van dic apostel. $\mathrm{Hy}$ is dus inderdaad diaken!

\section{(c) Epafras.}

In Kol. 4:12 en 1:7 noem Paulus hom 'n dienskneg (diakonos) van Christus. Opvallend dat hy tweemaal 'n dienskneg van Christus (diakonos) genoem word, asof dit 'n amptelike titel is. Hy bring dan ojk vir Paulus berig oor 'n saak wat met dic barmhartigheid verband hou nl. oor hulle "liefde in dic Gees". (Kol. 1:8). Het ons hier te doen met 'n diaken uit Kolosse wat Paulus as reisgenoot moet vergesel en versorg in opdrag van dia gemeente? Dit lyk baie waarskynlik.

Opsommend kan ons sê dat hierdie manne amptelik deur hulle gemeentes opdrag gegee is om die apostel te versorg, om die gawes van dic gemeente aan hom oor te bring en om aan dic gemeente verslag te doen oor die welstand van die apostel en om verder die apostel te help in alle sake waarin hy hulle hulp nodig het, II Tim. 4:12; Tit. 3:12, veral as skakel tussen die apostel en die gemeentes insake die barmhartigheid. Dit is opmerklik dat hierdie manne nou verbonde aan 'n besondere gemeente is: Epafroditus aan Filippi; Epafras aan Kolosse; Tichikus aan Efese.

(d) Die ,goedgekeurdes".

Die gawe (charis) van die heidengemeentes is na Jerusalem deur ,goedgekeurde' manne oorgebring (I Kor. 16:4 en II Kor. $8: 22$ ). Die werkwoord dokimazein dui beslis op ' $n$ verkiesing van hierdie manne: geskik ag deur oorweging. ${ }^{\circ}$ ) Het ons hier $m=t$ diakens van die gemeente te doen? Dit lyk tog so.

\section{7. ... en Fébé.}

Die kernopdrag van dienende versorging het mesgebring dat ook vroue tot die diakensamp gekies is. Hierdie verdere ontwikkeling van die diakensamp bring geen nuwe opdrag by nie; eerder is dit ' $n$ intensivering van die eintlike opdrag aan die diaken. Teen die tyd as Fébé in Kenchreë dien, het dic woord diaken al op die voorgrond getree as omskrywing van die besondere amp.

Vraag is of ons hier met ' $n$ vrou in die amp van diaken te doen het. Dat Fébé 'n besondere plek in die gemeente beklce het, blyk baie duidelik uit Rom. 16:1 en 2. Sy moet deur die gemeente "ontvang word in die Here", en hulle moet haar "bystaan in elke saak waarin sy julle nodig mag hê." Sy sou die

4) W. Bauer, Worterlouch: ,, S.V. 
gemeente dus gebruik! Hierdie sake roep baie vrae na vore wat die beste beantwoord word as ons hierdie gedeelte so verstaan dat Fébé 'n diaken gewees het. Hierom word sy dan nie sondermeer 'n diaken genoem nie, (dan sou ons haar gewoonweg ,dienares' kon noem!) maar ,diaken ... van die gemeente in Kenchreë". Alle twyfel oor haar ,amptelikheid" word uit die weg geruim as Paulus nou sê dat sy vir baie en ook vir hom 'n beskermster ${ }^{18}$ ) gewees het. Sy het die apostels en ander reisigers ter wille van-die-evangelie in haar huis ontvang en hulle versorg. Hiertoe het sy amptelike opdrag gehad.

\section{I. Tim. 3.}

I Tim. 3 maak duidelik onderskeid tussen die ampte vanuit die vereistes wat aan elkeen gestel word. By die ouderling val die klem op die regeer-bekwaamhede - by die diaken op die bekwaamheid om met mense om te gaan. Tot opsig en regering het die diaken geen gawe ontvang nie en word dit ook nie van hom verwag nie.

Ons het hier glad nie met 'n status-verskil te doen nie. Eers na die jaar 200 is die diakensamp aan die van die biskop gesubordineer. Die diaken word hierna orgaan van die biskop en mag sonder die medewete van die biskop nie gewigtige sake afhandel nie. $\left.{ }^{49}\right)$ Hoe is die verhouding van ouderling en diaken? Die Bybel ken geen vertikale orde in die amp nie. Van 'n minderwaardigheid en 'n ondergeskikte plek teenoor die ouderling kan hier nie sprake wees nie. Vanuit Hand. 6 en die in volgorde naas mekaar plaas van Filip. 1 kan ons wel van 'n horisontale volgorde praat. (Van Ruler!) Vraag is wat dit dan sou inhou? Sou dit in die praktyk beteken dat die ouderling se opsigtaak ook oor die diakensamp strek sonder om die diaken afhanklik en ondergeskik aan die ouderling te maak? Hierdie horisontale volgorde kom ook tot uitdrukking in die feit dat die diaken op sy besondere manier bystand vir die apostel is. (Epafroditus, Tichikus, en Epafras).

By Ignatius (C. $35-$ C. 107) vind ons dan ook nog hierdie verhouding van horisontale volgorde tussen biskop, presbyter en diaken nl. dat hulle "medediensknegte" is en dat die diaken dienende begeleier van die biskop is.

In die lig van bogenoemde lyk dit noodwendig dat die Kerkorde van die Nederlandse Hervormde Kerk lees:

„De diakenen werken bij de vervulling van hun opdracht samen met de andere ampsdragers der gemeente". (Ord. 15, Art. 3,1 . Vergelyk ook Calvyn, Inst., IV, IV, 5).

48) Prostates het 'n sterk tegnies-amptelike en religieuse aspek.

49) So in die Apostoliese Konstitusies en Apostoliese Kanonieke. 


\section{WAT IS DIE INHOUD VAN DIE AMP VAN DIAKEN?}

\section{A. DIE REFORMATORE EN DIE VUL VAN DIE DIAKENSAMP.}

Ons het gesien dat die Reformasie Christus se amp sterk beklemtoon het en dat die ampte hierom in die kerk toe ook sentraalgodsdienstige betekenis gekry het. Eers toe Christus se amp weer reg verstaan is, kon daar tot die regte vul van die diakensamp gekom word.

\section{Luther.}

Rondom die diakensamp stel Luther veral drie sake telkens.

(a) Besorgdheid dat die diakensamp soos ons dit in die Bybel vind verdwyn het. ${ }^{\mathrm{s} 0}$ )

(b) Die diakensamp het nie die opdrag om die evangelies of die briewe te lees nie. By Stephanus se amp is daar nie sprake van tonsure en allerhande seremonies nie. ${ }^{51}$ )

(c) Die diens van die diaken is om die armes te versorg. Die diaken is voog oor die armes. Sy werk bestaan in die uitdeling van die gawes en om die krankes te besoek..$^{52}$ )

\section{Calvyn.}

In sy Institusie IV, III, 9 handel Calvyn kort en volledig oor die diakensamp. Die sorg van die armes is aan die diakens opgedra. Vanuit Rom. 12:8 onderskei Calvyn twee soorte diakens. Die wat die aalmoese beheer en die wat die armes versorg. Onder die tweede soort val o.a. die weduwees van I Tim. 5:10. ${ }^{\text {i3 }}$ ) Handelinge 6 is die oorsprong, instelling en ampsopgawe ${ }^{54}$ ) van die diakensamp. Calvyn wys daarop dat in die dae van die apostels en voor die pousdom, die diakens die gifte van die gelowiges ontvang het en dit dan vir die juiste gebruik aangewend het; dit is om dit deels aan die dienaars (ministris), deels aan die armes uit te deel tot hulle onderhoud. (IV, iv, 5. So ook die Lutherse Kerkorde van 1566).

3. Inhoud van die diakensamp.

(a) Afgrensing.

(i) Die diakensamp is nooit bedoel om vakleerlingskap vir enige ander amp te wees nie. Dit sou die barmhartigheidsdiens maak tot ' $n$ minderwaardige en minder belangrike amp in die kerk.

so) W.A. 10, I/1; 262, 16-263, 10.

i) W.A. 6, 566, 34 .

52) W.A. 6, 566, 34; W.A. $10 \mathrm{I} / 1 ; 262,16-263,10$

53) Nullum enim aliud publicum officium obire mulieres proterant, quamsi in obsequium pauperum se darent.

s-) Origio, institutio ac functio. 
(ii) Die diaken is geen faktotum nie. Alhoewel die diakensamp nooit geisoleerd staan of censaam is nie, het die diaken 'n besondere opdrag. Rome het ons geleer dat juis die handizheid van die diakensamp ons nie moet verlei nie - so dikwels as wat die diakensamp vreemd aan sy opdrag gevul is, so dikwels het hy prakties verdwyn.

(b) Die opdrag aan die diaken.

(i) Die diakensamp is, soos alreeds gesê, nooit geisolcerd of censaam nie. Hiermee word bedoel dat die barmhartigheidsdiens no:jit doel op sigself is nie. Die diakensamp staan in diens van die evangelie. Sy amp is om te sorg vir die stoflike sodat die evangelie sy voortgang kan hê. (Versorging van die dienaars). Of as armversorging het die uitvoering van sy amp die grootn:aak van God se Naam voor oë. Uit die Bybel is dit duideli' dat die diakensamp altyd in samehang met die ander ampte gesien most word. Maar hierdie ,saamwees" moet ons nie laat dink dat hy 'n faktotum is nie. Hy het 'n besondere opdrag tot barmhartigheidsdiens. Die diakensamp is nooit eensaam nis, maar tog besonder. Vanuit die besondere genadegawe wat tot elke amp verleen word, kan ons nie eiesinnig die funksie van cen amp op 'n ander oordra nie.

Die diakensamp hou beslis nie die regeermag in nie. As hy s am met die ander ampte is, is dit om te dien, nie om te regear nie. Ons is beslis besig om die diakens in hulle eintlike, hoë en heilige amp en diens - die diens van die barmhartigheid - te strem deur hierdie ekstra verantwoordelikheid op hulle te laai. Die eizsinnige belading van die diakensamp sal daartoc bydra dat die diens van die barmhartigheid wegkwyn. ${ }^{.57}$ )

(ii) Vanuit Hand. 6 moet ons dit so verstaan dat die diaken by die Nagmaal sal by wees. Daar is 'n onlosmaaklike verband tussen diakonia en koinónia. Sy amp ontspring by die koinónia en het koinónia ook as doel. (Het die Reformasie ook dié verband beklemtoon?)

(iii) Die kerk het dit nog altyd so verstaan dat siekebesoek en siekeversorging die werk van die diaken is. Die Reformasis sien die diaken as dienaar en nie as "liturg" nie. Die swaartepunt van sy werk lê nie in die erediens nie, maar daarbuite. ${ }^{\text {*it) }}$

iii) B. J. Engelbrecht. Die Amp van die diaken, bl. 34 .

iii) Tóg stel Calvyn: .,Dat aan hulle egter ook die voorlees van die evangelie vir die volk opgedra is. en die aansporing tot aanbidding - soos wat hulle ook gebruik word om die beker by die Heilige Avondmaal aan te gee - dit het geskied om nulle amp te versier. sodat hulle juis dit met groter noukeurigheid sou voltooi, sodat hulle deur sulke tekens daaraan herinner sou word dat dit nie een of ander profane huishouding as wat hulle bestuur het nie. (non esse profanam aliquam villicationem quam gererent) maar ' $n$ geestelike en Godgewyde diens (sed spiritualem et Deo dicatam functionem). Inst. IV, IV, 6. 
Hier kom 'n reeks dringende vrae na vore. Wat is die verhouding tussen koinónia en diakonia? Sal hiérdié verhouding nie die swaartepunt van die diakens se diens by die erediens plaas nie? Waarom het die diakensamp by Rome en Church of England tot 'n bloot liturgiese verval? Is dit omdat hulle die swaartepunt by die erediens geplaas het? Is die Reformatoriese aksent reaksie?

En verder: Is die tafeldiens van Handelinge 6 nie ook diens in die erediens nie?

En ten slotte: Wat is die historiese oorsprong van die diens wat die diakens by ons in die erediens verrig? Hierdis aksent lê by die kerkwet swaar, waar gehandel word oor die werksaamhede van die diakens. (Kerkwet van die Ned. Herv. Kerk van Afrika. Bepalinge Hoofstuk XVII, Artikel 173, c, d, e.)")

(iv) Die „Kerkorde der Nederlandse Hervormde Kerk”, laat die diakonaat ook gestalte kry in "het dienen van die Kerk in haar taak om overheid en sameleving te wijzen op haar roeping ten aanzien van de sociale vraagstukken de gerechtigheid te betrachten".

A. B. van N. Herbst het daarop gewys dat die kerk as sodanig verantwoordelik is vir die opvoedingsproses rondom die ckonomie van die volk..$\left.^{5 *}\right)$ Hierdie ,.. . maar, leer 'n man om vis te vang en jy doen beter" en die "sosiale geregtigheid" het die diakonaat, sous die Wêreldraad van Kerke dit sien, al by vreemde plekke uitgebring. Moet hierdie taak daarom uit die werksaamhede van die diakens uitgelaat word? Is dit nodig dat die persoonlike, nederige dienskarakter van die diakonaat verlore gaan as hy op die breër terrein van owerheid en samelewing beweeg? Is die diakonaat in die gestalte van diakonein die kerk se antwoord op die sosiale nood of moet die diakonaat ook ander gestaltes aanneem? Is die kerk slegs ,askar van die ekonomie"? (Herbst). Ten slotte: lê die sosiale vraagstukke en maatskaplike verhoudings op die arbeidsveld van die diaken?

\section{EKSKURSIE: DIE VROU EN DIE DIAKENSAMP.}

Of 'n vrou die diakensamp mag beklee, is geen besondere probleem nie. Die geskiedenis van die kerk ken dan ook baie geleenthede dat vroue die diakensamp beklee het. Dat die vrou ook die diakensamp beklee, is nie soseer in enkele tekste gefun-

ii) Kan die diaken vanuit die begrip diakonein orie in die erediens handhaaf? Tog nie!

i) Dic Christen-Afrikaner en die Ekonomie, Referaat gelewer op die Nasionale Kultuurkongres te Pretoria op 25 Oktober 1968. 
deer nie, maar in die begrip diakonein in die besonder en as breër agtergrond die Bybelse siening van die vrou. Omdat die diens die eintlike van die diakensamp en die opdrag aan die vrou is, was dit in die Nuwe Testament en die geskiedenis „vanselfsprekend" dat vroue ook die diakensamp gevul het.

\section{A. KEN DIE NUWE TESTAMENT VROUENS WAT DIE DIAKENSAMP BEKLEE?}

Dit kom dikwels in die Nuwe Testament voor dat vroue dienswerk verrig. Hiervan is Martha seker die bekendste voorbeeld. In Joh. 12:2 berei hulle te Bethanië vir Jesus 'n maaltyd, . . . en Martha het bedien". Ons lees in Luk. 8:3 van baie ander (vroue )wat Hom almal met hulle besittings gedien het. Van Tabita word gesê: „Sy was oorvloedig in goeie werke en aalmoese ..."Hand. 9:36. Hierdie is verdere voorbeelde van diens vanuit die ,amp van die gelowige”. Hier sien ons dan dat gelowige vroue uit dankbaarheid diens aan die Here bewys, sonder dat daar enigsins sprake van 'n besondere amp van diaken is. Ook by die verkiesing van die weduwees (I Tim. 5:9 vervolgens) moet daar op gelet word of hulle ,bedruktes gehelp" het. Ook hier het die vroue voordat hulle 'n besondere opdrag gekry het, barmhartigheid bewys.

Die sterkste aanduiding van $\mathrm{n}$ vrou wat die diakensamp vervul het, kry ons in (i) Rom. 16:1 nl. Fébé ,wat 'n dienares (diaken) is van die gemeente in Kenchreë". Sy was 'n beskermster vir baie en ook vir Paulus. Die woord ,prostátēs' (beskermer) het vanuit sy etimologie altyd 'n baie sterk godsdienstige en amptelike kleur. Calvyn verbind dan haar amp met die van die weduwees in (ii) I Tim. 5, waar ons 'n verdere sterk aanduiding kry dat vroue in die ou gemeente 'n amptelike plig gehad het. Uit die voorskrif tot die verkiesing is dit duidelik dat hierdie vroue besig was met die barmhartigheidsdiens of dat hulle soos Fébé die ellendiges „beskerm” het. (iii) I Tim. 3:11. Alhoewel oor die uitleg van hierdie gedeelte meningsverskil bestaan, lyk dit tog of hier ook voorskrifte is vir die verkiesing van vroulike diakens. Bepalend is hierdie gedeelte vir die hele vraag egter nie.

\section{B. HOE SAL ONS HIERDIE AMP VUL?}

Die eintlike vraag is hoe ons die amp van die vroulike diaken sal vul.

(1) Bybelse siening van die vrou.

Die wyere veld van die Bybelse siening van die vrou in die algemeen en haar besondere taak in die gemeente sal hier bepalend wees. 
In Spreuke 31 is dit duidelik dat ook wanneer die vrou buite haar huis bedrywig is, haar bedrywigheid altyd op haar huis gerig is. Die eintlike wat ons van die vrou kan sê, is dat sy 'n versorgster is. En alhoewel haar versorging ook buite haar huis strek, lê die swaartepunt nie buite haar huis nie, maar rondom haar huisgesin.

Wat die huwelik betref, leer die Nuwe Testament 'n onderdanigheid van die vrou aan die man. Hierdie onderdanigheid het 'n baie besondere betekenis omdat dit heilsekonomie is en nie bedoel is om die vrou in ' $n$ minderwaardige posisie terug te druk nie. Hierdie ongelykheid van die man en die vrou het Christus en die gemeente in die oog. Die inhoud van hierdie onderdanigheid kom dan ook uit die heilshuishouding van God: „Maar soos die gemeente aan Christus onderdanig is, so moet die vroue dit ook in alles aan hulle eie mans wees". (Ef. 5:24).

Omdat ons hier te doen het met God se verhoudingbepaling as heilswerk, is dit 'n misverstaan van die hele evangelie om hier te spreek van rang of status, want hier gaan dit nie om rang of status of posisie nie, maar om diens en liefde en redding en heiligheid. Daarom is dit vanselfsprekend dat hierdie verhouding nie net 'n huweliksverhouding is nie, maar verhouding wat ook in die gemeente deurloop. As mens dit vergeet sal I Kor. 11:3-12 en I Kor. 14:34 vir 'n mens onversoenbare teenspraak inhou en ook heeltemal onduidelik wees. Dan sal mens na eksegetiese kunsgrepe moet gryp om uit jou dilemma te kom. Dat 'n vrou in die gemeente sal bid en profeteer (die profesie is tog gawe van die Gees en die gebed smeking deur die Gees) is die ,normaalste' saak ter wêreld. Verder moet onthou word dat profesie nie identies is met onderrig gee en prediking nie. ${ }^{59}$ ) Wanneer die vrou profeteer moet sy 'n teken van gesag op haar hoof hê.

\section{Enkele opmerkings by II Kor. 11:2-16.}

(a) Dit gaan hier om sedelike plig (opheilei) en skeppingsordening. Die bedekking van haar hoof is vir die vrou 'n beskerming en teken dat sy die man as hoof (kephalē) het.

(b) Dit gaan nie om reëling binne die familie nie, maar om reëling in die erediens. Gemeentevrae en nie huweliksvrae nie, is hier aan die orde. Dit gaan om die wese van die man en die vrou in die algemeen. Paulus voer baie argumente aan, maar die verhouding man en vrou in die huwelik, kom hier nooit ter sprake nie.

59) H. Berkhof, De Leer van de Heilige Geest, Nijkerk 1965, bl. 100. 
(c) Artikelgebruik kan in hierdie geval nie vir ons uitsluitsel gee of hier sprake is van man en vrou in die huwelik of in dic algemeen nie.

(d) Dit gaan hier nie om die kultiese minderwaardighe:d van dis vrou nie. Hier is vroue wat profeteer!

(e) Ons het hier met 'n verskeidenheid in die eenheid te doen. (I Kor. 11:11, vgl. Gal. 3:28).

In I Kor. 14:34 gaan dit oor die diskusseer (lalein) van die vrou ens. in die gemeente, want vers 35 bepaal die inhoud van lalein (spreek) as mathein (ondervra, diskusseer). $\left.{ }^{\prime \prime \prime}\right)$ Om te diskusseer hou in dat 'n gesagsposisie beklee word. En die gesagsposisie is nooit die plek van die vrou nie. (Sy is beskermster, nie regeerder nie!) Hierom moet die vrou in die gemeentebyeenkoms swyg. (In die gemeentebyeenkoms leer sy nie en moet sy onderdanig wees). (I Kor. 15:34; I Tim. 2:12!) (Nogmaals hup Jtassain, maar as bevel!) Dat die vrou enige plek van gesag in die gemeente sou beklee, is teenstrydig met haar skepping, roeping en opdrag as hulp, beskermster en onderdanige. Om te sê dat die vrou in haar onderdanige dienswerk 'n minderwaardige posisie bekles, sou dieselfde wees as om die nederige dienswerk en gehoorsaamheid van Christus te minag en te verkleineer. Smelik tipeer die houding van die man en die vrou mooi as hy sê: ,mannen spreek en vrouen zyn". Ons het dus nooit te doen met die onmondigheid van die vrou nie, maar ons het te doen met haar besondere Godgegewe plek nl. dat sy nie oor die man sal heers nie. (oude authentein andros I Tim. 2:11!) As S. Kierkegaard hierdie gedeelte (I Tim. 2:11-12) uitlê, sê hy dat die swye van die vrou nie daarin bestaan dat sy nie praat nie, maar dat dit op haar besondere manier van praat dui.

As Paulus in I Kor. 11 en I Kor. 14 die besondere plek van die vrou bepaal, doen hy moeite om aan te toon dat hy hier nie met 'n nuwe eiesinnige voorskrif kom nie. Dit is bevel van die Here (I Kor. 14:37) en gewoonte van die gemeentes (I Kor. 11:16).

(2) Afgrensing.

(a) In die vulling van die amp van die vroulike diaken kan dit nooit daarom gaan of die vrou ook manswerk kan doen of selfs beter kan doen nie. Die Kerk sou 'n streep deur die evangelie trek as hy die vrou sondermeer tot ekwivalent van die man wil maak. Die christelike vrou sou haar eie wese en veral roeping misken as sy in slaafse navolging van die man hom gelyk wil wees of wil oorheers (authentein).

6.1) Mathein as diskusseer vgl. T.W.z.N.T. IV., S. 394. So ook Paulus in Gal. $3: 2$ ! 
(b) Vanuit haar natuur is die christelike vrou waarskynlik beter as die man toegerus om die diakensamp te vervul. In dic ampsvervulling gaan dit egter nooit om natuurlike aanleg nie, maar om die gawe van die verhoogde Heer.

(c) Dit kan vir die Kerk nojit daarom gaan om by die moderne gemeenskap aan te pas nie sodat die vrou nou ook in die kerk ten volle die man se gelyke sal wees nie.

(d) Die vrou kan nooit tot diaken gekies word omdat daai' nie mans gevind kan word nie; dit sou tog van haar 'n tweede keuse maak. Tot die amp word die geskikste mense gekies (1 Tim. 5:3), nie die beskikbares nie. Die kies van die vrou tot dic diakensamp kan ook nie geskied as oplossing vir die probleem dat die ,geskikte" nl. die man, nie beskikbaar wil wees nie. Hier moct die tug toegepas word nie die verkiesing gehou word nie.

\section{(3) Maar hoe dan gevul?}

Waar die Nuwe Testament van vroulike diakens praat, kry ons cok die vulling van hulle amp.

(a) I Tim. 5. Die weduwees is besig met die versorging van die armes. Calvyn sê hulle sorg vir die armes, behoeftiges en s:ekes. Inst. IV, III, 9. Hulle is nie besig met die insameling en beheer van die aalmoese nie, maar met die versorging van dic armes self. Só vind ons hulle dan amptelik besig in Wesel, 1568, 1575. 1578, 1580. Mannen spreek en vrouen zyn!

(b) Rom. 16:1. Fébé is as diaken 'n beskermster van die wat sorgbeho=wend is. 